\title{
Contemporary types of energy-efficient buildings: an architectural and structural review
}

\author{
Sergey Stetsky ${ }^{1, *}$ and Natalya Galaeva ${ }^{1}$ \\ ${ }^{1}$ Moscow State University of Civil Engineering, Yaroslavskoye shosse, 26, Moscow, 129337, Russia
}

\begin{abstract}
The article discusses the modern state of architecture and construction in the world, aimed on saving energy through specific architectural and structural design of buildings. It is noted that for the time being energy saving in the majority of countries is nearly the main problem, and that is a challenge for contemporary architecture and construction. There are some ways of efficient solution of the problem in question. Among these the design and construction of special types of buildings seems to be the most notable.
\end{abstract}

\section{Introduction}

Among different and various types of houses and buildings being in use nowadays there are some special types, which distinguish from the whole lot mainly in terms of energy consumption. Such buildings are called "passive" and feature sufficient energy saving due to specific architectural and structural design solutions. "Passive" buildings in general can also be classified as follows:

i/- Buildings which are energy-efficient due to complete or partial insulation of their building envelope (underground houses or houses set into grade) [1-7, 11, 14].

ii/- Buildings which are energy-efficient due to solar energy utilization ("solar houses"). These can use solar radiation either with the aid of solar collectors/batteries or through the implementation of special architectural and structural design solutions (say, "Tromb's walls", winter gardens or greenhouses, etc.)

\section{Theoretical background}

All types of buildings mentioned above can be determined as "passive" buildings. These are objects in which energy efficiency is reached with architectural and structural means. Energy conservation and requirements for environmental protection are leading factors to favour building underground. Other factors might be safety and privacy. Main examples of these buildings are completely underground houses with patio, usually square in plan, and partially underground houses, such as buildings set into grade or mountain villas (Figures 1, 2 and 3).

\footnotetext{
${ }^{*}$ Corresponding author: sergioni1947@gmail.com
} 


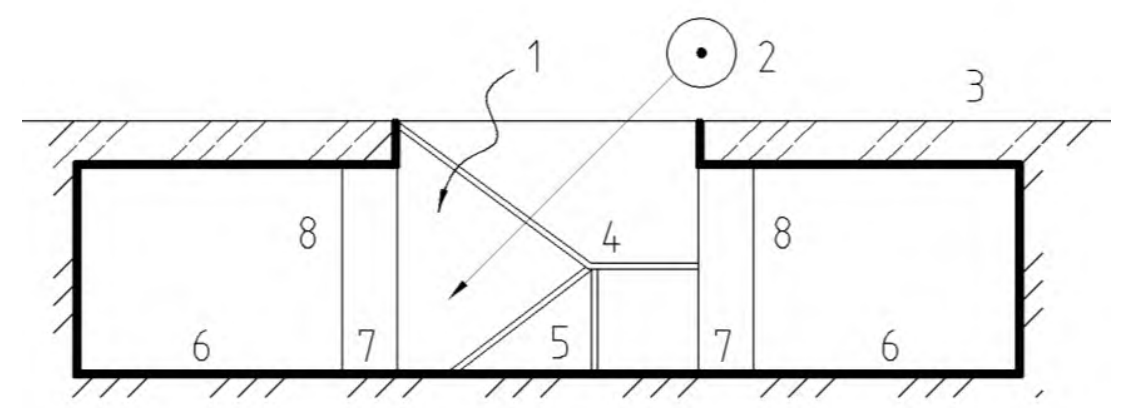

Fig. 1. Underground house. Key: 1 - natural ventilation; 2 - insolation and natural lighting; 3 ground level; 4 - stair; 5 - patio; 6 - living room; 7 - corridors/galleries; 8 - glazed partitions.

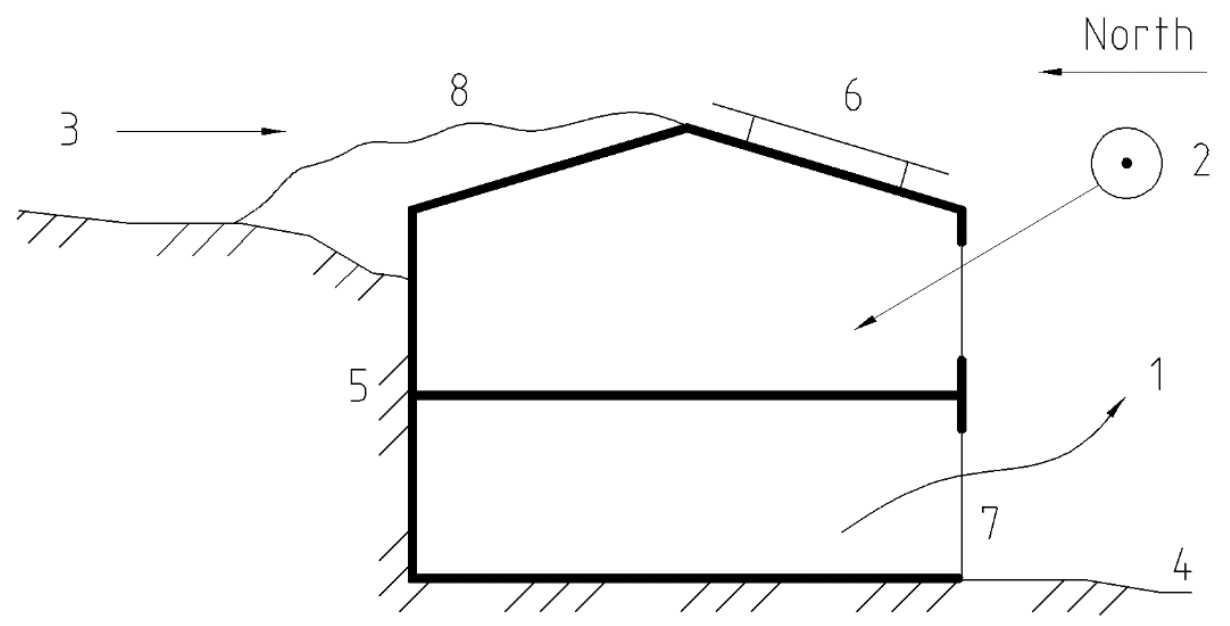

Fig. 2. Building set into grade. Key: 1 - natural ventilation; 2 - insolation and natural lighting; 3 - prevailing winds; 4 - ground level; 5 -a blind wall; 6 - solar collector/battery, as an optional version to gain electric power; 7 - glazing; 8 - snow deposits in wintertime.

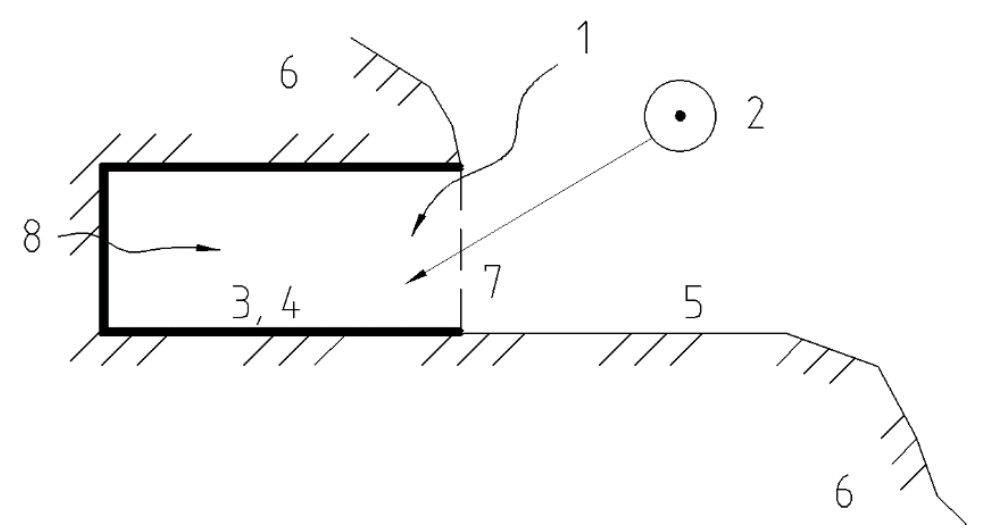

Fig. 3. A mountain villa. Key: 1 - natural ventilation; 2 - insolation and natural lighting; 3 - partially open ventilated area in summertime, with high position of the sun; 4 -thermal pocket; 5 - terrace; 6 - mountain slopes; 7 - an adjustable glass screen; 8 - internal volume of a dwelling. 
Design of "solar houses" is based on such structural and planning solutions that can ensure solar energy utilisation. This process also can be either active or passive, the latter being of most interest for our study. Active solar energy utilisation is usually in form of solar collectors/batteries to gain electric power due to sun radiation. This power is used either to cool the interior of a dwelling or to heat it. Passive utilization means usage of natural conditions to the best advantage in order to gain more natural sun heat and to decrease heat losses. Hence orientation, exposition to the sun, cold wind protection, windbreak planning, etc. play a very important role (Figures 4 and 5) [1, 2, 8-14].

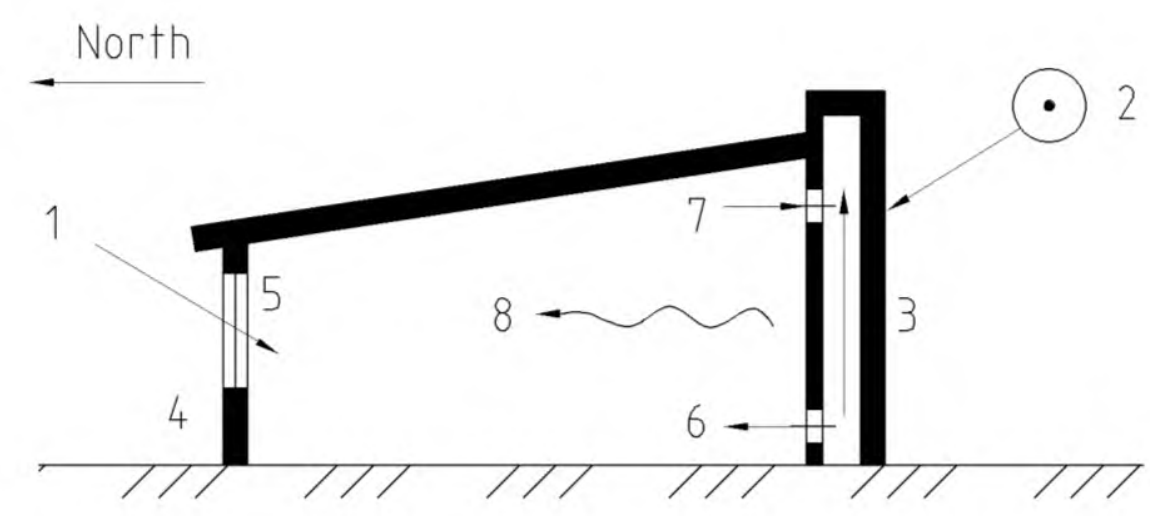

Fig. 4. A solar house with structural heating through Tromb's wall. Key: 1 - natural ventilation and lighting; 2 - solar radiation; 3 - thick heavy-mass concrete wall with ducts (Tromb's wall); 4 - thick light concrete wall; 5 - glazing; 6 - outlet; 7 - inlet; 8 - heat flow.

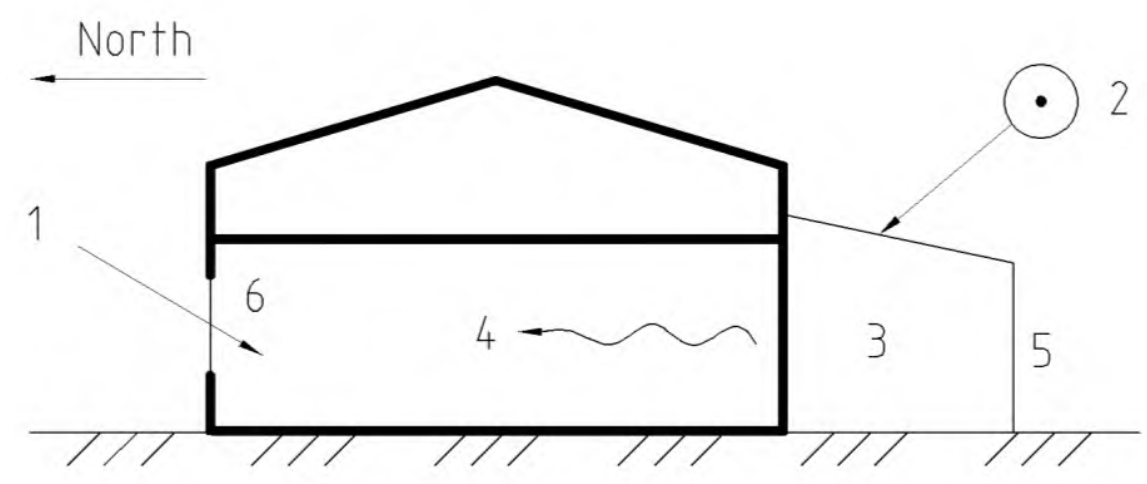

Fig. 5. A solar house with winter garden/greenhouse. Key: 1 - natural ventilation and lighting; 2 solar radiation; 3 - winter garden or greenhouse; 4 - heat floes; 5 - complete glazing of a winter garden or greenhouse; 6 - window's glazing.

The main idea of the article presented is to compare planning and structural solutions of the buildings discussed on criteria of physical/technical properties, i.e. on possibility to create comfortable microclimate environment of the dwellings considered.

\section{Desk study}


These are some advantages and disadvantages in creating comfortable microclimatic environment in the interiors of "passive" buildings. The environmental characteristics can be evaluated through the quality of specific physical and functional regimes, such as natural ventilation and illumination, thermal insulation, solar insolation and sun protection, visual/psychological contact with surrounding environment, ecological aspects (protection of nature), privacy, etc.

The analytic evaluation of these regimes is presented in Table 1

Table 1. The evaluation of main physical/functional characteristics of indoor environment for different types of "passive" houses

\begin{tabular}{|c|c|c|c|c|c|c|c|c|c|c|c|}
\hline \multirow[b]{2}{*}{ 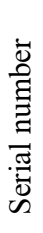 } & \multirow[b]{2}{*}{$\begin{array}{l}\text { Type of a } \\
\text { passive } \\
\text { building }\end{array}$} & \multicolumn{9}{|c|}{ Appraisal of physical/functional characteristics of interiors } & \multirow[b]{2}{*}{$\begin{array}{l}\text { Additional } \\
\text { notes }\end{array}$} \\
\hline & & 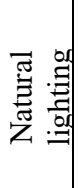 & 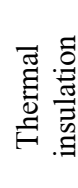 & 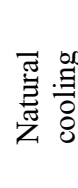 & 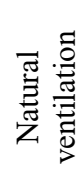 & 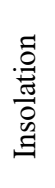 & 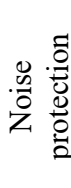 & 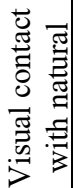 & 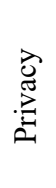 & 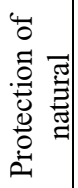 & \\
\hline 1 & 2 & 3 & 4 & 5 & 6 & 7 & 8 & 9 & 10 & 11 & 12 \\
\hline 1 & $\begin{array}{l}\text { Underground } \\
\text { house } \\
\text { (Figure 1) }\end{array}$ & 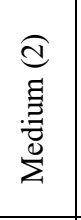 & 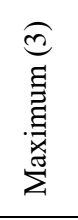 & 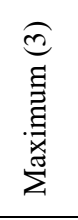 & 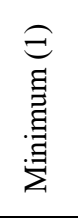 & 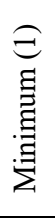 & 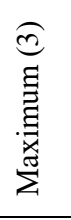 & 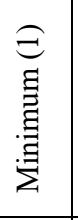 & 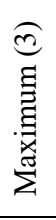 & 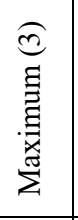 & $\begin{array}{l}\text { The } \\
\text { average } \\
\text { result of } \\
\text { evaluation } \\
\text { is } 2,22 \\
\text { points }\end{array}$ \\
\hline 2 & $\begin{array}{l}\text { Building set } \\
\text { into grade } \\
\text { (Figure 2) }\end{array}$ & 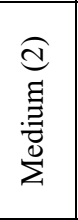 & 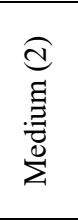 & $\begin{array}{l}\text { త্ } \\
\text { 䇂 } \\
\stackrel{e}{\Sigma}\end{array}$ & 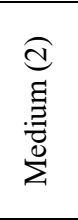 & 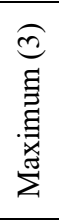 & 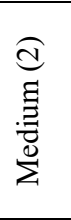 & 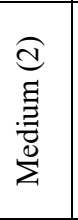 & 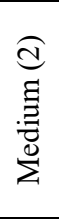 & 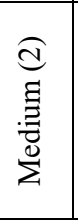 & $\begin{array}{c}\text { The } \\
\text { average } \\
\text { result of } \\
\text { evaluation } \\
\text { is } 2,11 \\
\text { points }\end{array}$ \\
\hline 3 & $\begin{array}{c}\text { A mountain } \\
\text { villa (Figure } \\
\text { 3) }\end{array}$ & 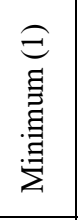 & 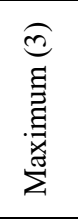 & 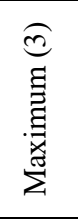 & 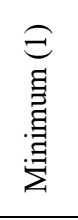 & 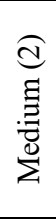 & 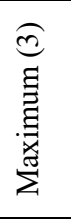 & 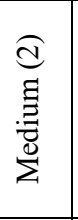 & 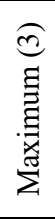 & 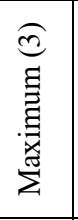 & $\begin{array}{c}\text { The } \\
\text { average } \\
\text { result of } \\
\text { evaluation } \\
\text { is } 2,33 \\
\text { points }\end{array}$ \\
\hline 4 & $\begin{array}{c}\text { A solar } \\
\text { house with } \\
\text { Tromb's } \\
\text { wall (Figure } \\
\text { 4) }\end{array}$ & $\begin{array}{l}\widehat{\Xi} \\
\Xi \\
\text { 音 } \\
\text { 声 }\end{array}$ & 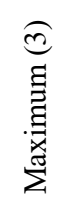 & $\begin{array}{l}\text { త্ } \\
\text { 章 } \\
\stackrel{e}{\Sigma}\end{array}$ & 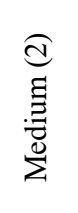 & 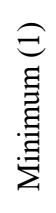 & 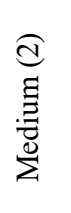 & 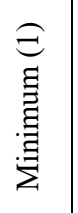 & 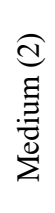 & 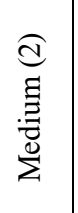 & $\begin{array}{l}\text { The } \\
\text { average } \\
\text { result of } \\
\text { evaluation } \\
\text { is } 1,77 \\
\text { points }\end{array}$ \\
\hline 5 & $\begin{array}{l}\text { A solar } \\
\text { house with } \\
\text { winter } \\
\text { garden or } \\
\text { greenhouse } \\
\text { (Figure 5) }\end{array}$ & 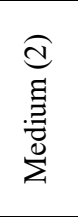 & 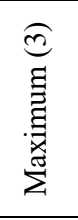 & 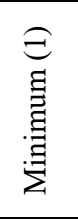 & $\begin{array}{l}\overparen{d} \\
\Xi \\
\stackrel{\Xi}{\Xi} \\
\stackrel{d}{\Sigma}\end{array}$ & 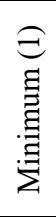 & 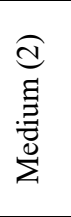 & 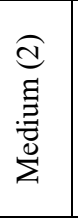 & 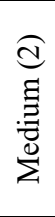 & 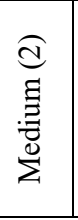 & $\begin{array}{l}\text { The } \\
\text { average } \\
\text { result of } \\
\text { evaluation } \\
\text { is } 1,88 \\
\text { points }\end{array}$ \\
\hline
\end{tabular}

Note. Maximum degree of appraisal equals to 3 points, medium - to 2 points and minimum - to 1 point. 
The appraisal is conducted on 3-point evaluation scale: maximum, medium and minimum values of properties considered. As it is clearly seen from Table 1 data, none of the building types considered are ideal from the physical/functional point of view. The routine case is to reach better characteristics of a certain internal microclimatic regime at expense of another. Say, with big windows the natural lighting becomes better, but noise protection and thermal insulation becomes worse, etc. Hence the best result, which might be expected, is to achieve a reasonable "optimum solution". The optimum set of microclimatic characteristics achieved by passive means must be combined with some active means, say with artificial lighting and air conditioning.

\section{Conclusions}

The analytical study discussed above gives the opportunity to make some conclusions, which are as follows:

$\mathrm{i} /-$ According to the analysis of data from Table 1, the best, though not ideal, case of the "passive" houses considered is case number 3 , which is an example of a mountain villa. The worst position shows a house with Tromb's wall (case number 4). The difference, however, is not dramatic: the average results lay from maximum of 2,33 points to a minimum of 1,77 points (on a 3-point scale).

ii/- The best result of the specific characteristics in every case considered shows the factor of thermal insulation, which is maximum nearly in every type of "passive" houses in question. This fact shows the greater validity of thermal protection as compared with other factors in question. It shows that all the types of the "passive" houses considered have the design solution primarily aimed on thermal insulation, maximum heat gain and minimum heat loss. Extra heat gain may be stored by energy conservation means and afterwards used, for example, for supplementary artificial lighting of interiors or other necessary energy charges.

iii/- The study shows that there are two main ways to reach an ideal planning/structural design solutions of the houses in question, aimed on reaching comfortable indoor microclimatic environment. The first one is based on the best energy conservation solution of a dwelling, either underground or a solar one. To this object a number of other means are being added, aimed on natural lighting, ventilation, noise protection, etc. control. Such a combination may lead the whole design solution to the best advantage. The second way is to design a passive type of a dwelling with a set of planning and structural means discussed above, which firstly match each other within the main idea of a design in spite of other efficiency and afterwards to improve all the disadvantages of microclimate created with artificial means of indoor environment climatisation.

\section{References}

1. N. M. Gusev, "Fundamentals of Building Physics" (Moscow, Stroyizdat, 1975)

2. A. K. Soloviev, "Environmental Physics" (Moscow, ASV Publishers, 2014)

3. E. Harkness, M. Mehta, "Solar radiation control in buildings" (Moscow, Stroyizdat, 1984)

4. T. G. Maklakova, "Function, structure and composition in architecture" (Moscow, ASV Publishers, 2002)

5. "Solar shading for low-energy buildings". European Solar-shading Organisation Report, Edition 1, Meise, Belguim (2012) 
6. “Understanding overheating - where to start?" A guide for house builders and designers. N.H.B.C. Foundation (Milton Keynes, Great Britain, 2012)

7. N. Knoop, «Visual, health and environmental benefits of windows. New eye on existing buildings» 5th "VELUX" Daylight Symposium, May 2013. The Royal Danish Academy of Fine Arts. School of Architecture, Copenhagen, Denmark

8. S. V. Stetsky, A. D. Serov, The specifics of comfortable microclimate creation in office buildings for climate conditions of Near East countries, 12 (Moscow, PGS, 2017)

9. S. V. Stetsky, E. G. Lobatovkina, The perfectisation of subjective expert appraisal method for indoor microclimate factors, 8 (Moscow, PGS, 2013)

10. A. V. Palagin, A. I. Sterkhov, E. V. Korepanov, Comparison of natural lighting systems of buildings according to functional-energy factors, 2(24) (Moscow, Intellectual systems in industry, 2014)

11. A. K. Soloviev, Passive houses" and energy effectiveness of their architectural and structural elements, 4 (PGS, 2016)

12. E. Ne'eman, R. Hopkinson, Critical minimum acceptable window size: a study of window design and provision of a view, Lighting research and technology, 2(1) (1970)

13. B. Steck, "European practice in the integration of lighting, air conditioning and acoustics in offices" Lighting Research and Technology, 1(1) (1969)

14. R. Gajewski, P. Peniazek, "Building energy modeling and simulations: qualitative and quantitative analysis" XXVI R.S.P. Seminar "Theoretical Foundation of Civil Engineering" MATEX Web of Conferences 117, 00051 (2017) 